\title{
Nature-Society and Development:
}

\section{Social, Cultural and Ecological Change in Nepal}

Final version of this manuscript can be found in Geoforum, Volume 34, Issue 4, November 2003, Pages 525-540

\section{Andrea Nightingale}

Geography,

School of GeoSciences,

University of Edinburgh,

Edinburgh EH8 9XP,

Scotland

andrea.nightingale@ed.ac.uk

fax: +44 (0) 131 650-2524

phone +44 (0) 131 650-2526 


\section{Copyright}

This online paper may be cited in line with the usual academic conventions. You may also download it for your own personal use. This paper must not be published elsewhere (e.g. mailing lists, bulletin boards etc.) without the author's explicit permission

Please note that :

- $\quad$ it is a draft;

- $\quad$ this paper should not be used for commercial purposes or gain;

- you should observe the conventions of academic citation in a version of the following or similar form:

Andrea J. Nightingale (2006) Nature-Society and Development: Social, Cultural and Ecological Change in Nepal, online papers archived by the Institute of Geography, School of Geosciences, University of Edinburgh. 


\title{
Nature-Society and Development: Social, Cultural and Ecological Change in
}

\section{Nepal}

\begin{abstract}
This paper presents a theoretical framework for analyzing human-environment issues that examines shifting, dialectical relationships between social and power relations, cultural beliefs and practices, and ecological processes to allow an interdisciplinary, complex assessment of social and environmental change in Nepal. The purpose of this analysis is to capture the complexity and non-static nature of environmental and social change in the context of uneven development. Drawing from political ecology and feminist geography, this framework brings together scholarship on aspects of human-environment issues that are often pursued in isolation, yet all three processes, social-political relations, cultural practices and ecological conditions, have been acknowledged as important in shaping the trajectory of social and ecological change. I argue that a consideration of the articulations between them is necessary to understand first, how specific land management regimes arise and are dominant over time in specific places. And second, I examine the extent to which these regimes distribute resources equitably within communities, promote economic development and sustain ecological resilience. In this analysis, ecological processes are conceptualised as co-productive of social and cultural processes to explore their role in land management regimes without resorting to environmental determinist or similarly reductive paradigms. I present this framework through the example of natural resource management, specifically community forestry in Nepal, as it offers a rich case study of the relationships between the political economy of land use and the ecological effects of natural resource extraction.
\end{abstract}


Keywords: political ecology, human-environment interactions, development, natural resource management, Community Forestry, Nepal 


\section{Nature-Society and Development: Social, Cultural and Ecological Change in}

\section{Nepal}

\section{Introduction}

Human-environment issues remain central to the international development agenda and the complexity of the society-environment nexus has been acknowledged by a shift from development programs focused on specific resources such as community forestry, to programs focused on livelihoods and integrated development. Geographical scholarship is this realm has been approached from a variety of theoretical perspectives that draw from population geography, political economy, Marxism, postmodernism and other post-structuralist theories (Adams 1990, Agrawal and Sivaramakrishnan 2000, Batterbury et. al. 1997, Blaikie 1985, Blaikie and Brookfield 1987, Bryant 1998, Peet and Watts 1996a, Peluso 1995, Richards 1990). Despite theoretical diversity, this research has shown that the intersection of social and ecological factors is critical in determining the character and direction of both ecosystem change and development outcomes. Power, politics, knowledge, social differentiation, economic development, livelihood quality (often understood as both social and environmental), and ecological resilience have emerged as particularly salient aspects of human-environment issues. Yet few theoretical models and corresponding methodological approaches are able to understand these factors as integrated and variable over time, space, scale and specific context. Existing scholarship has been strained by the need to incorporate the complexity of ecosystems, the imperfect knowledge we have about their functioning, and the complexity of political economic systems rooted in cultural and geographical processes (Sneddon 2000). 
This paper presents a theoretical framework for analyzing development that examines shifting, dialectical relationships between social and power relations, cultural beliefs and practices, and ecological processes to allow an interdisciplinary, complex assessment of social and environmental change. The purpose of the framework is to capture the complexity and non-static nature of environmental and social change in the context of uneven development. The theoretical arguments are illustrated through an example of natural resource management, specifically community forestry in Nepal, as it offers a rich case study of the interactions between the political economy of land use and the ecological effects of natural resource extraction.

At core, this conceptualization brings together scholarship on aspects of human-environment issues that is often pursued in isolation. Such isolation produces ecological solutions that are not socially tenable and often undermines the cultural and political contestations that result. The formation of national parks and biosphere reserves to promote environmental protection in many Third World countries are good examples (Scott 1998, West and Brechin 1991). National parks have often deprived local residents of critical natural resources without providing for sufficient replacements such as alternative fuels, and jobs that would allow the purchase of replacement resources. Similarly, development programs that are formulated in the absence of an ecological analysis have undermined ecological resilience in many ecosystems. For example, the drilling of wells to improve small holders' livelihoods in Bengal and Bangladesh has resulted in dangerously high levels of arsenic in drinking water due to over-exploitation of ground water (Abdi 1999). Finally, explanations that try to account for increased pressure on resources due to population increase often neglect to account for the complex, context-specific and multi-scalar 
causes of ecological decline which are not easily reducible to population change (Arizpe et. al. 1994).

By investigating the intersection of social-political relations, cultural practices and ecological processes, the influence of these processes on each other and the role of environmental conditions in producing uneven development are highlighted without resorting to environmental determinist or other similarly reductive paradigms. I use the idea of land management regimes to encompass the overall (transient) outcomes of these intersecting processes and to reflect the dominant institutional, social and daily practices associated with land use. The ultimate goal of this analysis is to understand how particular land management regimes become dominant over time and space through the intersection of society, culture and ecology and the implications of this dominance. I highlight these aspects because scholarship to date has focused on the importance of analyzing them (Peet and Watts 1996a) but rarely has one author addressed all three.

Social and power relations include but are not exclusive to, caste, class, race and gender relations, and in the Nepalese case, political party membership. These axes of difference do not operate independently but rather, different elements of peoples' identities combine in complex and subtle ways to influence their degree of social and political power (Nightingale 2002a). Cultural practices is an analytical domain that I define to encompass beliefs about nature and meanings attached to land as well as other cultural beliefs. These cultural elements shape the range of land management decisions people will consider and therefore are critical to understanding how environmental transformations occur. Ecological conditions vary with the specific issue, but human land use has a huge impact on which species of plants and animals are dominant in a particular place (Grimm 1984, Zimmerer 1994). Ecological 
conditions in turn, shape the beliefs and practices that arise in relation to particular landscapes. Therefore, as I will demonstrate more fully below, a consideration of all three domains is necessary to understand how specific land management regimes arise and are dominant over time in specific places, and also the extent to which these regimes distribute resources equitably within communities, promote economic development and sustain ecological resilience.

Dialectical thinking would conceive of social and power relations, cultural practices and ecological conditions as internal relations (Harvey 1996 p. 49-54), that is as domains that in many ways are not separable, but for the purposes of analysis are understood as producing and reproducing each other. While I have defined these as relatively self-contained, drawing clear boundaries between them is problematic because they are co-constitutive and embedded within each other. Changes in one domain cannot be understood in isolation from relationships with other domains, part of why human-environment issues are so complex and difficult to theorize, much less solve. This becomes particularly evident in the inchoate boundary between social and power relations and cultural practices. For example, while I have defined caste as a social relation, it can also be argued that caste is a cultural practice. Here I use the relationships between the social-political, cultural and ecological to provide an analytical starting point to explore some of the contradictory and multifaceted dynamics of natural resource management. It is crucial, however, to keep the fuzzy boundaries between these analytical domains in the forefront of the analysis to highlight the complexities and unpredictability of the society-culture-environment nexus. Also, by focusing on three domains instead of two (i.e. society-culture and ecology), this analysis attempts to disrupt the binary thinking that can plague dialectics (Harvey 1996 p. 46-68, Shields 1999 p. 109-126, 160-163, Soja 1996 p. 53- 
82).

In the next section I introduce community forestry in Nepal and the user-group with whom I worked most closely. The following section lays out the intersections between and the importance of the relationships identified above, and section four elaborates on this framework through the example of community forestry.

\section{Community Forestry in Nepal}

Community forestry in Nepal is an excellent example of the intersections of the social-political, cultural and ecological. ${ }^{1}$ Nepal was one of the first 'tropical' countries targeted as an ecosystem in crisis by international environmentalists during the 1970s. Deforestation from Himalayan hillsides was believed to cause an increase in soil erosion, and eventually catastrophic flooding in the northern Indian Gangetic plain. In this discourse, deforestation was largely attributed to peasant livelihood strategies, including their farming practices, population growth, and poverty (Gilmour and Fisher 1991). ${ }^{2}$ Community Forestry programs arose out of these discourses of ecological crisis and forest degradation in Nepal largely promoted by international development organizations. Today it is a government-sanctioned program that turns management of national forests over to village users, called "user-groups."

The projects were based in development models that focused on villagers' basic needs, but fundamentally were concerned with protecting 'fragile' forest ecosystems. In the beginning, the projects exclusively grew tree plantations on denuded slopes and prevented villagers from poaching resources (Graner 1997). Overtime, the program changed focus, however, and it is now oriented around 4 main goals: (1) providing for villagers' basic needs, especially for the poorest of the poor; (2) promoting economic development through the sale of forest products; (3) instilling 
democratic institutions into communities in the hills; and (4) conserving forests (Gilmour and Fisher 1991, Graner 1997). The projects thus clearly integrate both social and ecological goals.

In Nepal forests have become the focus of many development efforts in part because they are considered critical for survival and the gathering of forest products occupies a large portion of most women's time. Villagers use composted leaf litter and animal manure as their primary source of fertilizer and gather firewood for cooking and green leaves for animal fodder. They also cut timber and let animals graze on understory plants. The sale of forest products varies from one place to another, but in general, timber for local consumption (and wider consumption where transportation is adequate), firewood, leaf litter and especially medicinal and herbal plants are potential forest commodities (Edwards 1996). ${ }^{3}$ Community forestry promotes the management of forests as a common pool resource, (cf. Ostrom 1992), based on management plans villagers develop with the help of District Forest Office (DFO) staff. The projects often improve forest conditions, and the democratic, locally based structure of the user-groups is consistent with the government's decentralization goals.

Most analyses of community forestry to date have followed the literature on common property and tried to understand the local institutional and spatial characteristics of user-group development (Acharya 2002, Kanel and Varughese 2000, Kharel 1993, Shrestha 1996, Springate-Baginski et. al. 1998) My analysis here tries to demonstrate that by analyzing community forestry within the conceptual framework I propose, a different understanding of the program is obtained, one that takes account of the multi-scalar and complex relationships that more fully explain why community forestry has been very successful in some places and not in others. 
The discussion is based on intensive research I did in Mugu District of northwestern Nepal with one community forest user-group and peripherally with other nearby user-groups. The user-group is considered to be one of the best in the district because it has succeeded in producing evident improvements in forest structure by increasing seedling recruitment, and it at least nominally includes a cross-section of users in the management of the forest. Caste relations are particularly salient in this group as only recently have feudal labor relations based on caste taken on less importance and caste continues to be significant in defining social difference and power. Similarly, gender relations continue to be important in defining control over resources and the division of labor both within households and communities (Nightingale 2002a, Nightingale 2002b).

In the next section I outline my proposed framework for exploring questions of equity and resilience in community forestry. This work has arisen out of political ecology and feminist geography but attempts to focus on the intersections of processes that have been more intensively explored by other literature in this field.

\section{Power, Culture and Political Ecology}

Within geography, political ecologists have expanded our understanding of human-environment issues by insisting on the linkages between capitalist development and ecological change, and interrogating other social influences on the environment. The insights offered by early work included 'chains of causality' that showed how over-exploitation of resources by impoverished land owners was inextricably linked to political-economic processes operating at larger scales (Blaikie 1985, Blaikie and Brookfield 1987). By demonstrating how population and local poverty were not solely responsible for resource decline, political ecology draws into question the accepted explanations for forest degradation in Nepal and elsewhere. 
Early political ecology analyses, however, failed to theorize the mechanisms by which control and access of resources and property rights were defined, negotiated, and contested at multiple scales; specifically within the political arenas of the household, the workplace, and the state (Peet and Watts 1996b, p. 9). Without such a theorization, political ecology could not demonstrate how relations of production, institutional arrangements and affluence also lead to environmental degradation (Peet and Watts 1996b).

Later work, best represented by Liberation Ecologies, (Peet and Watts 1996a) attempted to address these gaps by first, theorizing the linkages between capitalist development and land management (Bryant 1998). Second, giving greater attention to social relations and power at all scales has provided a clearer analysis of politics within political ecology (Batterbury et al 1997, Bryant 1998, Freidberg 2001, Moore 1996, Rangan 1997). Third, the discourses and contexts within which knowledge about ecology and land use is generated have been more carefully interrogated (Bryant 1998, Lakshman 1993, Nesbitt and Weiner 2001, Zimmerer 1996). And finally, this work has argued for more attention to the dynamic nature of ecosystems and the historical contexts of ecological change (Scoones 1997, Sneddon 2000, Zimmerer 1994, Zimmerer 2000). Yet, these aspects of human-environment issues have generally been explored by different authors; in this paper I explicitly link them together to explore the importance of their intersections. In the next section, I discuss in more detail the insights offered by political ecology and why I argue more attention needs to be paid to the interrelationships of the aspects outlined above. I focus first on the influence of social and cultural relations on ecological conditions, and then on the influence of ecology on both of these. The case study in section four elaborates in more detail on how these interrelationships play out in a specific context. 


\subsection{Social relations, cultural practices and ecological conditions: capitalist development, labor relations and ecological change}

The importance of social relations and cultural practices for ecological change has been illustrated by studies examining how capitalist development and productive relations influence land management regimes at different scales. ${ }^{4}$ Many political ecology case studies have emphasized how productive relations and labor allocation in localities are shaped by interactions between multi-scalar social relations and everyday acts of resistance (Bebbington 1996, Carney 1996, Jarosz 1996, Moore 1996, Schroeder and Suryanata 1996). For example, changes in relations of production—generally influenced by capitalist development on a global scale—have been important catalysts motivating people to migrate from rural, agrarian areas to urban, or other industrialized centers (Deere 1990, Radcliffe 1992). Antecedent social relations and cultural beliefs about work are important determinants of the age, gender and racial composition of migrants in different places (Radcliffe 1991), but in all cases, out-migration tends to leave behind a diminished and impoverished work force for agricultural production and associated natural resource management activities (Agarwal 1994). Labor scarcity in rural localities often causes people to neglect critical tasks that prevent soil erosion, maintain soil fertility and promote forest regeneration leading to negative impacts on the local environment. Affluence can also cause land degradation as in the case of wealthy ranchers seeking to clear rainforest land in Brazil for cattle grazing (Hecht 1985). These reallocations of land ('agrarian reforms') are often part of national development strategies and therefore also part of the process of capitalist growth (de Janvry 1981, Deere 1990) demonstrating how capitalism is implicated in environmental change. Theorizing 
changes in land tenure, labor allocation and resource use with capitalist accumulation and development is therefore critical for understanding human-induced ecological change.

Relations of work are another symbolic and material realm that influence land management regimes. Recent research by Gidwani (2000) has demonstrated the complex intersections between changes in the regional economy in northern India and labor relations. Social relations and cultural practices such as caste and class, effect the meanings of work and cultural expectations attached to particular work activities, allowing different segments of the community to profit in unexpected ways from an irrigation development project (Gidwani 2000). Thus, land management occurs through everyday work practices and as my own work in Nepal has shown, these practices are contested. People do not always follow established rules, often to resist (cf. Scott 1985) either the expectations of those more dominant or to establish their own authority, an example of contestations over social relations. These material struggles over resource use and work often have ecological and institutional consequences and therefore are important to consider in an analysis of development and environment-society issues.

Many political ecologists have emphasized the importance of gender relations within households and communities as a central part of social and cultural relations (Carney 1996, Freidberg 2001, Rocheleau et. al. 1996, Schroeder 1997). Feminist political ecology has investigated differences in access to resources defined by gender; gendered rights over resources and environmental quality; and gender relations in environmental social movements (Rocheleau et al 1996). This work has been important in emphasizing the importance of gender in structuring access to knowledge, resources and power (Rocheleau et al 1996 p. 3-6). Yet, as other feminist 
researchers have demonstrated, gender relations are important in not only structuring power, they are also constitutive of other social and cultural processes (Bondi 1993, Harris 2002, Massey 1994a, Nightingale 2002a, Scott 1991). Thus, the process of invoking and contesting difference is a critical way in which gender, caste, class and other social relations are defined, privileged and transformed in specific geographical and historical contexts (Kobayashi 1994, Massey 1994b, Scott 1991). My analysis here thus seeks to build upon the insights of feminist political ecology by interrogating not only how gender structures the impact of environmental concerns on different people, but also how gender is co-productive of environmental issues themselves.

Combining the insights of feminist political ecology and feminist geography, I argue that natural resource management is another context within which social relations, including gender, are constituted, contested and (re)produced not only within households and communities but also within the state and at other larger scales (see also Harris 2002, Nightingale 2002a). Natural resource management decisions are often equally embedded in contestations over caste, class, gender and other social relations as they are in ecological principles of resource use. An investigation of the multi-scalar contexts within which management decisions are made, and how difference is invoked and contested in these contexts as people seek to further their interests and identities is therefore critical for understanding the trajectory of land management regimes.

Closely related to the process of contesting social difference, cultural practices, such as beliefs about nature and meanings attached to land, intersect with social relations to affect how particular discourses about ecology become privileged and institutionalized. Zimmerer (1996) has described the way that people of different 
age groups within a Bolivian community constructed soil erosion problems in distinct terms, each group drawing on divergent beliefs to substantiate their claims. While this work has been important for understanding the logics of 'indigenous' knowledge (Peet and Watts 1996b p. 11-16), the association of people's beliefs with their identities freezes knowledge in time and space (Agrawal 1995). Yet as many authors have argued, knowledge is an active process (Haraway 1991, Longino 1990). An analysis of discourses that recognizes how the same people invoke contradictory beliefs and identities (Kobayashi 1994, Pigg 1996) begins to untangle the complex processes of knowledge production and its implications for ecological change. Discourses about ecological degradation can be powerful justifications for a variety of policy decisions made within stakeholder meetings or development organizations, yet people employ different discourses strategically to further their interests. Many of these discourses provide conflicting descriptions of the same piece of land, drawing into question how they are generated and contested. It is therefore necessary to examine where and how people draw on different beliefs to promote their land management objectives. Such an analysis avoids defining knowledge systems dualistically as "indigenous" or "scientific," and instead illuminates how different systems of knowledge are embedded in each other and the contexts within which knowledge claims are made and contested (Agrawal 1995, Haraway 1991, Latour 1987, Longino 1990).

Social relations and cultural practices are also embedded within the institutions that manage land and resources at different scales (Moore 1996, Peet and Watts 1996b, Rangan 1997). Social relations and discourses about ecology, land use and development are constituted, contested and reproduced through national and international institutions such as government planning and forest offices, development 
agencies, and environmental organizations such as the United Nations, International Union for the Conservation of Nature (IUCN) and the World Wide Fund for Nature (WWF). Institutions at local scales, including resource management user-groups, district and village level government offices and other, less formal local institutions are critical vehicles for these contestations and other interactions between localities and larger scale institutions. Thus the nexus of social relations and cultural practices have significant implications for the land management practices that result.

In addition to changes in social, economic and labor relations, political regime changes are equally significant. Democracy movements in the former Eastern block countries as well as in places like Nepal, have caused changes in the state's land management objectives and control over resources. Careful attention to the changing role of newly democratic governments in natural resource management is therefore critical for understanding the trajectory of environmental change. In Nepal, community forestry programs that were begun under the monarchy to satisfy villagers' basic needs have been revamped after the 1990 democracy movement as a vehicle for promoting democratic institutions and development in localities across Nepal (Gilmour and Fisher 1991, Guthman 1997, Häusler 1993, Kanel 1993, Shrestha 1999). ${ }^{5}$ How the state supports resource users and how it controls resources have significant ecological consequences as numerous examples from around the world have illustrated (Adams 1990, Bryant 1998, Moore 1996, Scott 1998). It is in this sense that social and cultural practices at multiple scales intersect with ecological conditions in addition to the other examples given above. What remains unaddressed, is how ecological conditions influence the constitution of and struggles over those social and cultural practices. 


\subsection{The ecological conditions of social relations}

My analysis of environment-society issues brings together the insights gathered from work on social relations and cultural practices with a non-static understanding of ecological conditions. Current work in ecology has shown that ecosystems are in a constant state of flux and thus the concept of climax or steady state vegetation types does not accurately describe the processes by which different ecosystems evolve (Botkin 1990, Gleason 1939, O'Neill 2001). Forests, for example, while remaining recognizably forests, undergo significant changes in the age and species composition of any given patch of forest over relatively short time scales (i.e. years, decades), leading not to predictable forest types, but rather to a large variety of types. This is particularly true in the forests of Nepal that have significant human harvesting of a variety of forest species (Stainton 1972). How to account for ecological change in relation to equally dynamic social-political and cultural processes is difficult because it is not possible to simply ascribe all observable changes in forest structure and composition to human harvesting practices. Some of these changes would occur regardless of human activity due to wind throw of canopy trees, foraging of wild animals, and other ecological processes (Dodson 1999) ${ }^{6}$ and we do not yet fully understand these processes nor do we have complete knowledge of them. It is therefore important to attempt to account for the dynamic interrelationships of the human-environment nexus without simplifying these relationships too much and bearing in mind our incomplete knowledge.

Within geography, a few authors have attempted to incorporate a dynamic understanding of ecology into political ecology (Scoones 1997, Sneddon 2000, Zimmerer 2000). Scoones (1997) has shown how pre-existing soil types, patterns of land use, and social relations at local scales are all critical factors in determining the 
extent to which soil fertility is a problem over time and space in Zimbabwe. He emphasizes that understanding environmental transformations requires investigating ecological changes over time, but that interpreting these changes is dependent both on which theory of ecology is employed and the time scales of the investigations (Scoones 1997 p. 162). Scoones' work in particular has demonstrated the importance of examining the dynamic nature of ecosystems and their historical trajectories of change.

Too few political ecology studies, however, critically engage with the ecological elements of human-environment interactions. Most literature in this field lacks a rigorous theorization of ecology and the data to understand ecological changes as more than simply a background, or a consequence of social-political struggles. Yet as I will demonstrate more fully below, ecological conditions and processes intersect with the social-political aspects of land management to influence the trajectory of human-environment interactions. Ecological conditions in a given locality are shaped by specific land use practices including agricultural techniques, grazing, resource harvesting, and clearing of forest land (Scoones 1997, Turner et. al. 1990). Ecological research has shown that these activities are significant determinants of species composition, recruitment and reproductive rates of particular species; soil fertility and erosion and; when these practices occur on a large enough scale, climatic events such as annual precipitation (Botkin 1990, Grimm 1984, Kates et. al. 1990, Tilman 1999, Zimmerer and Young 1998). As a result, land management practices as they arise out of the social-political processes outlined above, can alter or maintain particular vegetation types or other ecological conditions.

Vegetation types are not only determined by human land use, however, they are also the result of the seed dispersal mechanisms and migration rates of particular 
plant species (Gleason 1939, Turner 1990). Similarly, soil fertility is controlled by a variety of processes including, substrate weathering, leaching, animal and soil microorganism activities and plant types. The rate at which these processes are occurring is an important part of the overall trajectory of ecological change, and in many cases, they operate independently of human activities.

Understanding the mutually constitutive relationships between human socialpolitical and cultural processes and ecological processes allows for an examination of ecological thresholds and limits (loss of resilience) without trivializing the importance and complexity of human processes in the 'normal' development of most ecosystems. In addition, it allows for an examination of the influence of specific ecological processes on cultural practices and social relations. I will argue below that ecological processes also in part shape which beliefs about nature, resource use practices, and management organizations evolve in particular places. Social and cultural practices related to nature do not arise out of an ecological void, but are produced in particular historical, cultural and ecological contexts (Adams 1990, Cronon 1983, Moore 1996). While much attention has been paid to the former two, the effects of ecological conditions have been largely neglected in political ecology.

Political ecology and related literatures, therefore have demonstrated the importance of capitalist development, social and productive relations, discourses about land use, institutions and ecological processes in analyses of land management regimes. Yet many studies lack attention to all the issues raised under the diverse umbrella of political ecology in part because of the difficulties of doing so. Individual authors have chosen to address one or more of the political, cultural and ecological issues I have outlined, but few have attempted to understand how they are all embedded within each other. Given the complexity and uncertainties of these 
interactions, the framework I propose here is an attempt to conceptualize the intersections of these social, cultural and ecological processes. Perhaps most importantly, this framework makes dynamic ecological conditions more central while retaining a detailed and nuanced analysis of the social and cultural aspects of humanenvironment issues.

The three analytical domains-social relations, cultural practices and ecological conditions - in what we might call a trialectic, ${ }^{7}$ themselves are not fixed. Each is dialectically related to the other two, in an embedded, mutually constitutive manner that requires one to understand how they are all part of one highly complex process. The relative influence of these processes will depend on the context, requiring empirical investigations, but their interactions can be theorized. Also, as I have outlined above, it is not always possible to neatly separate them apart in the way that I have here. In particular, several geographers have argued that the divisions between nature and society are unstable and in many respects artificial (Braun and Castree 1998, Castree 2001, Castree and MacMillan 2001, Latour 1993). While I would agree that the boundaries between the social, cultural and ecological are artificial, it is nevertheless useful to separate them as an analytical entry point, keeping in mind their unclear boundaries and interrelationships. By conceiving of these relationships as trialectical, the framework theorizes the kinds of relationships that are salient to investigate while avoiding reducing human-environment issues to a binary relationship. It is also important to recognize that because these processes are rooted in the dynamics of place-based historical and cultural specificities, in addition to larger scale discourses of environment and development (Escobar 1995), the outcome of these articulations is variable from one locality to the next. I will now elaborate on this framework through a discussion of community forestry in Nepal. 


\section{Community forestry management in Nepal}

The interactions amongst social relations, cultural practices and ecological conditions are well illustrated by the experience of community forestry in Nepal. The formation of the program itself demonstrates the significance of social relations in determining which discourses about ecology become dominant and the corresponding promotion of particular land use practices. Western environmentalists in the late 1960s and early 1970s, heavily influenced by neo-Malthusian ideas of overpopulation and the carrying capacity of the earth, descried the apparent rapid deforestation in Nepal (Messerschmidt 1987, Shrestha 1997). Armed with these discourses of ecological degradation, combined with basic needs development models, the World Wide Fund for Nature and the United Nations Food and Agriculture Organization (FAO) persuaded the Nepalese monarchy to initiate programs in community forestry that were designed to encourage tree plantations on denuded slopes (Gilmour and Fisher 1991, Graner 1997). In this case, international power relations ensured that Western beliefs about ecological degradation prevailed over the Nepalese state to promote 'scientific' forest management in the hills. In addition, Forest Department officials were trained by international donor agencies and many of them have obtained Masters and Ph.D. degrees in various forestry departments in the US and Europe. ${ }^{8}$ Foreign degrees not only help to entrench Western ideas about forest management in Nepal, but for their holders they are also a source of legitimacy and power.

Early programs had variable success, largely because of the unexpected ways in which the programs intersected with local social relations. For example, the NepalAustralia Community Forestry Project found that some people with historical claims to the forest had been excluded from user-groups while other more powerful factions 
had co-opted groups (Gilmour and Fisher 1991). As a result of these findings, the project shifted its focus from growing trees on denuded slopes, to user-group formation and institutional development (Gilmour and Fisher 1991). Recently, all the foreign-donor supported community forestry projects have changed their names from 'forestry projects' to 'community development projects', reflecting a recognition that effective natural resource management is predicated on the fulfillment of health, education and income needs. Examining the projects within the framework proposed here, however, demonstrates how in fact community forestry as an institution is more fundamentally embedded in negotiations over social and cultural relations. In other words, both the growing of trees and institutional development are highly political and culturally specific processes and therefore it is not surprising that community forestry implementation needs to take account of both. Also, through acts of resistance and political struggles within localities, villagers assert their own beliefs, interests and social relations into the national conception of community forestry. Thus in this example, the multi-scalar articulations of social relations and cultural practices have produced particular manifestations of community forestry. Whether projects seek to protect trees or promote basic needs, these articulations are significant determinants of how projects play out on the ground and whether or not they will be successful.

In addition to contests over discourses of environmental catastrophe, social and power relations between and within institutions are contested in community forestry. For example, the user-group in Mugu District of northwestern Nepal mobilized to stop a proposal by the Nepali army to do live ammunition training in their community forest. The user-group president allegedly agreed to the training, but the rest of the user-group was opposed (interviews in Mugu February, 1999). They submitted official protests both locally and nationally to successfully stop the training. 
National level (or more powerful) interests, in this case the army, therefore do not always prevail in conflicts over land use. In very significant ways, people in localities have asserted their institutions, beliefs and practices to change national level policies related to natural resource management and land use.

Within localities, the institution of community forestry is a site where entrenched social and power relations and cultural practices are constituted, struggled over and (re)produced. In the above example, the president initially claimed leadership of the user-group based on his identity as a high-caste man from a family with a history of holding official positions, yet he was removed as president over the army incident. ${ }^{9}$ Community forestry for the most part has not succeeded in supplanting entrenched rural elites in Mugu. But the threat of losing the forest to the army was sufficient for this user-group to successfully resist the president's identitybased claims to leadership of forestry institutions.

Resistance, however, is often just that, and in Mugu has rarely succeeded in producing radical changes. A cousin, who similarly claimed legitimacy based on his heritage, replaced the user-group president. These identity-laden claims to power are extremely difficult for the user-group to contest. No one protested the grounds on which the successor claimed the position—as a member of a family who had a "right" to the presidency. It is taken for granted in Mugu that such claims to power are valid, even though they are in direct opposition to the stated objectives of community forestry.$^{10}$

The national goals of community forestry, therefore, are transformed in localities by local cultural practices into a site where social relations are contested, resisted and reproduced. At least in Mugu, community forestry is at best a contradictory mechanism for promoting true democracy. Community forestry 
programs seek the participation of women and low-caste members, but the extent to which their participation translates into real influence is closely related to power relations as they operate through caste, class, and gender (Nightingale 2002b). Given that the same people do most forest harvesting, the extent to which they are marginalized and react to their status through acts of resistance can have demonstrable ecological consequences. Acts of resistance that I've observed include cutting green wood and harvesting resources out of season or in prohibited areas, all of which have some affect on forest structure. As I will elaborate below, changes in forest structure can cause a re-negotiation of relations of production, group leadership and harvesting practices. It is in this sense that social and cultural relations and environments are coproduced.

The dialectical relations between wider cultural practices and ecological conditions display the same contradictory, complex and mutually constitutive characteristics. Beliefs about ecology, meanings attached to land and the formal and informal institutions formed to manage land (as they are embedded within social relations) shape which land management practices become dominant in particular places at specific times in history. Land management practices in turn have significant implications for ecological conditions and the future availability of resources as I described earlier. Discourses about severe ecological degradation in Nepal were crucial to the establishment of community forestry, imbuing the programs with understandings of ecology that derived from international environmental institutions. Yet, these understandings intersected with the beliefs, institutions and ecological conditions in localities to shape the enactment of land management in those localities, often producing significant variation between places. Such variation has an influence on the ecological impact of community forestry because of differences in 
land use.

As an example of how local cultural practices influence the implementation of community forestry, many of the forest management practices espoused by the national community forestry regulations are very similar to historical forest management in Mugu. Prior to 1957, many forests were managed under either informal or formal (government-sanctioned) village management institutions, with the village headman responsible for regulating resource extraction (Gilmour 1990, Messerschmidt 1987). In 1957 the government forest department took over the regulation of forests, but in most cases, so-called 'national forests' became effectively open access (cf. Ostrom 1992) and penalties for mis-use were inconsistently applied. Villagers in Mugu said that after the forests were nationalized they lost the ability to control access to their resources and at about the same time there was a rapid influx of migrants into the area, ${ }^{11}$ "There were more people, they dug more fields (khet, bari) ${ }^{12}$, they built houses. There wasn't anyone to watch the forest. If people asked for one tree, they cut 10," (interview with a Thakuri woman 20 February, 1999). Another woman added to this statement saying, "People would cut a small sapling for firewood, and all they would get would be three pieces of firewood... After that we all got together and formed the community forest... After the forest came into our own hands it is much better," (interview with a Brahmin woman 20 February, 1999). Community forestry has therefore returned control and regulation of harvesting to the user-groups.

User-groups in Mugu interpret their new roles in relation to their historical forest management regimes. When I asked people to describe historical forest practices to me they continually drew parallels with community forestry and contrasted it to the intervening period of state management. They spoke explicitly 
about how they had the knowledge to implement community forestry effectively because they had managed forests under the headman in the past. Other user-groups in the valley are believed to be less successful because historically they did not have a strong, effective headman. This example then, illustrates the ways in which new programs intersect with antecedent social and cultural relations, beliefs, practices and institutions, thus transforming the national objectives of the program.

In contrast to the similarities between $\mathrm{CF}$ and headman management, the practice of seasonal burning in the forest has changed substantially in Mugu with the implementation of community forestry. Historically, villagers burned the forest understory to promote the growth of grass for animal grazing. Fires add nutrients to the soil and eliminate most seedlings and saplings, promoting thick grass growth. These benefits, however, decline over time due to depletion of total nutrients in the system (Dahms and Geils 1997, Horn 1998) and have a negative impact on seedling recruitment. In addition, when periodic burning is combined with harvesting of mature trees for timber, the forest can degrade rapidly because there are not sufficient immature trees to replace the canopy trees that are cut down. The open, park-land type forests common near most villages in Western Nepal are due largely to fire and to some extent grazing (Stainton 1972).

It is not known for how long this practice has been common in Mugu, but many of the blue pines (Pinus wallichiana) have fire scars deep within their cores indicating that forest fires have been periodic over at least the past 70 years (Nightingale 2001). The gradual decline in grass growth, however, had not been attributed to regular burning until the establishment of the community forest. Government forest rangers, drawing from international forestry practices and scientific studies of fire, teach user-groups to prevent forest fires. The objectives are 
to increase the availability of firewood and to promote the production of timber trees by increasing seedling recruitment and preventing damage to mature trees. The usergroup I worked with quickly adopted this policy, working hard to educate all users about the problems with fire and actively suppressing fires that did start with the help of a broad cross section of users. Some areas within the forest are thick with seedlings and saplings no more than ten years old, corresponding to the establishment of the community forest and presumably the elimination of understory fires. Thus, a change in forest management practices related to fire has had a striking impact on the forest structure.

This example illustrates several of the issues I raised above. First, because the benefits of understory fires decline gradually over time, I postulate that the people in Mugu had not fully realized the long-term consequences of fire to their grazing areas. The power relations inherent in the promotion of a development strategy such as community forestry helped persuade villagers to adopt the new policy, but I believe it would not have been followed for long if tree seedlings had not begun to grow vigorously. Tangible ecological results provided critical evidence for villagers to accept the new policy and change dominant local beliefs.

Many people in the user-group talked about their fire suppression policy and pointed out to me the saplings that are the result. They referred to these stands of thick, young blue pines (Pinus wallichiana) as clear evidence of their care for the forest and successful implementation of community forestry. Community forests can be removed from village control if the District Forest Officer believes the villagers are mis-using the forest. Therefore, while blue pine is not the preferred species for fodder, leaf litter or even necessarily firewood (oak burns hotter and with less soot), ${ }^{13}$ the emphasis in $\mathrm{CF}$ on regenerating trees imbues blue pine saplings with potent 
symbolic meanings. The suppression of fires and the resulting new seedlings are central to discourses of forest improvement and the villagers' claims to the forest, making them equally important symbolically as they are materially. Fire suppression and its attendant cultural and material consequences is thus a good example of how ecological conditions are embedded within the beliefs and meanings attached to forests and forest management.

These locally-based cultural-ecological articulations closely mirror similar national and regional processes. As discussed above, community forestry programs themselves were initiated based on ecological change, both in Mugu and nationally. Large scale clearing of forests and corresponding landslides, particularly in heavily populated areas near Katmandu, led to the international outcry for forest preservation in Nepal $;{ }^{14}$ just as concern over rapidly declining forest resources in Mugu helped the villagers to accept the new program. As these examples clearly show, ecological conditions are in part constitutive of dominant social and cultural practices.

These relationships are further evident in the politics of control over land. Historically control over land in Nepal, especially control over forest land, has been a significant source of material and symbolic power. Extending as far back as the eighteenth century, Nepali monarchs (and later the Rana oligarchy 1846-1951) used land grants as a way to compensate military personnel and maintain the loyalty of other elites (Regmi 1988). In Mugu, according to local informants, the great, great grandfather of the current village headman was given land in Mugu and control over the forest although it is unclear what kind of grant this was (Nightingale 2001 p. 91117). Villagers were required to bring gifts of food and small amounts of money when they needed the use of resources such as trees for timber or extra leaf litter for roof insulation (interviews in Mugu, February-August 1999). In very important ways 
then, the person who controlled the forest was given social power through the respect and gifts given to him. Control over natural resources, especially valuable and rich resources, therefore is an important means by which people stake and maintain their claims to social and political power.

Conversely, the poor and marginalized suffer most when ecological conditions are poor. Research in other parts of South Asia has demonstrated the importance of forest and other communal resources for women, lowest castes and the poorest households (Agarwal 1994, Jodha 1986). These households are most dependent on common land for satisfying not only firewood and fodder needs, but also dietary requirements from collecting wild fruits and nuts, herbs ${ }^{15}$ and other resources (Agarwal 1994, Daniggelis 1994). Obviously distribution of resources (and not necessarily ecological conditions per se) is one main reason for the dependence of the poor on the commons, as the poor have inadequate productive lands of their own. But, in the context of poor transportation facilities that prevent the large scale importation of resources from other places, like in Mugu, and private property that is also suffering from drought, loss of soil fertility or other ecological decline, the poor are impacted most dramatically because of their lack of options.

In Mugu, the establishment of community forestry in the valley where I worked has further exacerbated powerlessness for particular groups of lowest-caste people, although overall the effect on social and power relations has been contradictory and complex (see also Nightingale 2002a). Within the user-group, the lowest-castes complain of the way that the higher-castes are able to dominate them when it comes to CF rules. As one Kami woman said, "They dominate (hepchhin) us, they don't give us permits, we can't even talk to them. We always have to do their work," (interview March 3, 1999). She went on to explain both the pros and cons of 
community forestry in the context of a dispute that had occurred when the lowestcaste women collected leaf litter without consulting the user-group. While community forestry has prevented the high-caste people from claiming the forest as exclusively theirs, it has not diminished their control over it.

Kami woman: Sahib, we are small [i.e. lowest-caste, powerless]. Some things we agree on, other things we don't agree on... over the forest, if we go there first, only then will there be fights. We are low-caste/servants (luhar) and they are high-caste/masters (bista). They asked us why we had gone to the forest without asking them. We have to mind whatever they say... They control us a lot (dabouchum). We have to give 120 rupees for the permit to cut [and sell fire] wood. We can only collect dead and downed wood for firewood. (interview March, 3, 1999).

She was particularly insistent that the permits for timber and firewood have added an extra burden to them because they are poor. When the forest was a national forest they technically needed permits but in practice did not buy them. Instead when confronted by District Forest Office rangers, they would plead their case based on their poverty and the rangers would most often let them off. Thus community forestry while increasing the material availability of resources, has reduced the availability of them to the poorest because of the need to pay for extraction of resources that are then sold.

Perhaps more dramatically, a forest controlled exclusively by a user-group comprised of lowest-castes has been unable to effectively exclude outsiders to the point where all the trees have been cut down. The District Forest rangers in 
interviews blamed the user-group for mis-management but an incident I observed in the village suggests caste-based power relations are more significant. A fight erupted on the trail in the village between some well-dressed (and thus presumably relatively wealthy) Chhetri girls and a lowest-caste Sarki girl from the lowest-caste user-group. When the higher-caste girls were chased off, I learned from the Sarki girl that she was under attack because she had reported the Chhetri girls after they stole firewood from her forest. The higher-caste girls were asserting their dominance through violence and trying to ensure they would not be reported again. From this incident, it seems quite likely that the lowest-caste user-group is not able to assert enough authority over their forest to prevent poaching because of the social power relations and cultural practices of caste (see also Nightingale 2001). Their poverty and their lack of power are exacerbated by poor ecological conditions which have not been mitigated by establishment of community forestry, but rather have further entrenched antecedent social relations and led to further ecological decline.

Social relations, played out in the context of natural resource management, thus also have demonstrable ecological consequences. Other authors have argued that much of the forest degradation evident today in Nepal is not recent, but rather is the result of taxation burdens imposed under the Ranas and earlier kings (Metz 1991). Closer to Kathmandu, the Rana regime focused on extracting taxes in the form of agricultural produce and timber. Forests were therefore cut both for timber and for the clearing of agricultural fields in the nineteenth century and early part of the twentieth century leading to the kind of conditions seen today (Mahat et. al. 1986). In contrast to these studies, the work I did in Mugu indicates that the forest management regime, established by the Rana government and administered by the village headman, was reasonably effective in promoting 'sustainable' use of forest resources. 
Oral histories in Mugu indicate that until the forests were nationalized, forest conditions were thick, wild (jangali) and plentiful. One 74 year old man indicated that the timbers for his house came from an area about 215 meters lower down the valley than any forests occur today. After nationalization, however, the loss of village control over the forests led to relatively rapid decline. They blame three key factors for this: loss of control, the influx of migrants and the establishment of a nearby National Park which reduced the total grazing area available to them (Nightingale 2001). The kinds of dominant tenure arrangements, taxation burdens, and forest regulations, (social relations and institutions) in localities therefore, were significant in determining the state of ecological conditions when CF was implemented and producing variation between places.

My work also revealed that the two main reasons people presently make ecologically poor management choices in Mugu are either because of contestations over social relations, or resistance to the expectations of those more powerful than themselves. Social relations within the user-group are important determinants of who makes decisions within community forestry. In Mugu, women and low-caste men are largely excluded from the management decision making process in multi-caste usergroups. Caste and gender norms require that they sit away from the high-caste men who run the meeting, literally and symbolically dimming their voices at meetings. Even when they do voice their concerns, these concerns are very rarely addressed by the final outcome (Nightingale 2002b). High-caste men also use the user-group process as a way to consolidate and bolster their social and political power. It should be mentioned here that, like many Third World countries, personal connections and influence are the keys to moving ahead in life. Admissions in prestigious institutions of higher education, job placement and access to training, government resources and 
similar contexts are all dependent on who you know in political positions and whether or not they owe you any favors. Personal ambitions, giving and receiving favors, and the always critical need to build a power base, therefore, are often placed ahead of the ecological necessities of community forestry. This is not to imply that villagers (either the men who control the process or those who are more marginalized) are ignorant of good forest management or that they are not concerned about conserving their resources. On the contrary, in several instances the user-group committee changed their approach to controversial management decisions-decisions that were made largely for political reasons-because of the potential ecological consequences. Nevertheless, it is clear that social relations are invoked, negotiated and contested in the context of community forestry and these struggles can have ecological consequences.

Decisions based on political ambitions and acts of resistance can have ecological affects, although other common property studies have indicated that some flexibility is necessary to maintain such institutions (McKean 1992). Women, children, lower-caste men, and anyone who feels disenfranchised from the community forest management committee, do on occasion, harvest green wood for firewood (only dead wood is allowed), cut more trees for timber than their permit specifies, or graze animals during prohibited months of the year. These are often acts of resistance against either the expectations of in-laws in the case of women, the dominance of the higher castes in the case of the lower-caste sawyers, or disagreement with the management objectives of the community forest. In addition, in the case of cutting timber, there are significant economic incentives as low-caste men can make more money cutting timber than they can at any other job open to them. It should be noted that the degree to which the forest structure and resilience are compromised by these 
acts of resistance is dependent on the cohesion of the user-group (thereby limiting resistance) and the scale of harvesting. Anything beyond small scale poaching would be noticed and considered an act of open rebellion punishable by a fine, and therefore not likely to be done by members of a strong user-group. Social relations thus intersect with ecological conditions in multiple and complex ways, just as they intersect with cultural practices, to shape the extent of ecological change and equitable distribution of resources within communities.

\section{Conclusion}

The framework I have presented in this paper illuminates the complex ways in which the processes of social and power relations, cultural practices and ecological conditions intersect to drive land management regimes in particular historical and geographical contexts. Political ecology has developed a strong base from which analyses of human-environment interactions can be investigated, but this work is greatly enriched by understanding ecological conditions and processes as internally embedded in the social and cultural process of human land use. It is not adequate to understand the biophysical environment as simply a background when analyzing resource use. Rather the kinds of resources available, their rates of regeneration, the kinds of disturbances that either increase or decrease the abundance these resources, and their overall trajectory of change over time, contribute to the formation of particular kinds of social and power relations and cultural practices. All of these then combine to drive land management.

Similarly, beliefs about nature, meanings attached to land, and the institutions formed to manage land (cultural practices), influence the kinds of land management options and implementation strategies people will consider. Yet these beliefs are 
context specific and cannot be associated with particular groups of people in a static way. Rather, knowledge about ecosystems is constructed in particular land management contexts, a process that is intimately connected to negotiations over identities, interests and claims to authority. Concurrently, social relations are often contested and reproduced within the context of resource management through struggles over who controls particular institutions, who is expected to implement what kinds of work, and, ultimately, who controls which resources. Simple overarching explanations based on the assumption that increasing pressure on resources undermines 'traditional' common property institutions fail to capture the contextually rooted causes of institutional and ecological decline. How community forestry will be implemented and whether it will improve forest resources is inextricably linked to these historical and geographical specificities. By understanding ecological conditions in a trialectical relationship with social relations and cultural practices, the complex and often contradictory effects of each on the others is revealed. This kind of analysis, therefore, allows for a deeper understanding of the processes that shape land management and human-environment interactions more generally.

This analysis also points to the importance of case studies in understanding complex human-environment interactions. I have argued that antecedent social relations and cultural practices transform nationally and internationally promoted projects at more local scales. Currently, many development projects are conceived at international scales and resource management projects that are successful in one place are then implemented in much different contexts. ${ }^{16}$ The analysis I've presented here, however, indicates that such large scale planning is inappropriate for most resource use contexts. Rather, context-specific social-political and biophysical variables drive the outcome of project implementation and therefore will produce variable results 
from large scale schemes.

Land management ultimately governs whether or not social equity and ecological sustainability are possible. Equitable distribution of resources and democratic access to decision making are inextricably embedded within the kinds of struggles and negotiations over social relations and cultural practices that I've described. Ecological sustainability is similarly entwined with the articulations between these social-political processes and ecological processes. The analysis I have suggested provides for a rich, detailed understanding of these processes and points to solutions that will account for such complexity.

\section{Acknowledgements}

Numerous people and institutions in both the United States and Nepal supported the work for this paper. I would like to express a special thanks to Eric Sheppard who was extremely helpful in the development of earlier drafts. I'd also like to thank Helga Leitner, Vinay Gidwani, and Gabriela Valdivia, from the University of Minnesota Geography Department, and the MacArthur Scholars Program Gender Network for their support and intellectual contributions. In Nepal, I would particularly like to thank the US Fulbright Commission, His Majesty's Government of Nepal, Mike Gill, Bishnu Maya Pariyar, Hem Laxmi Shrestha, Narayan Kaji Shrestha, Meera and Keshav Ban, Manisha Gautam Dhakal and the people of Chaina, Hernikanth and Sangkhola. The comments of three anonymous reviewers and Jennifer Robinson were extremely helpful in developing the final draft. Any errors that remain are my own. The research and writing of this paper was supported by a US National Science Foundation (NSF) Graduate Fellowship, National Science Foundation Doctoral Dissertation Improvement Grant No. 9900788, a Fulbright-Hays 
Doctoral Dissertation Award, a Doctoral Dissertation Fellowship from the University

of Minnesota Graduate School, and the MacArthur Scholars Program on Global

Change, Sustainability and Justice. I am deeply grateful for the support they have

provided.

\section{References}

Abdi S.N.M. 1999. Hooked on Arsenic. In Himal South Asia

Acharya K.P. 2002. Private, Collective and Centralized System of Institutional

Arrangements in Community Forestry in Nepal. Presented at The Commons in an Age of Globalisation: the Ninth Conference of the International Association for the Study of Common Property, Victoria Falls, Zimbabwe.

Adams W.M. 1990. Green Development. New York: Routledge

Agarwal B. 1994. A Field of One's Own: Gender and Land Rights in South Asia. Cambridge: Cambridge University Press

Agrawal A. 1995. Dismantling the Divide Between Indigenous and Scientific Knowledge. Development and Change 26, 413-39.

Agrawal A., Sivaramakrishnan K. 2000. Introduction: Agrarian Environments. In Agrarian Environments: Resources, Representation and Rule in India, Agrawal, A, Sivaramakrishnan, K (Ed.), pp. 1-22. Durham: Duke University Press.

Arizpe L., Stone M.P., Major D.C. 1994. Population and Environment: Rethinking the Debate. Boulder: Westview Press. 352 pp.

Batterbury S., Forsyth T., Thomson K. 1997. Environmental Transformations in Developing Countries: Hybrid Research and Democratic Policy. The Geographical Journal 163(2), 126-32.

Bebbington A. 1996. Movements, Modernizations, and Markets: Indigenous organizations and agrarian strategies in Ecuador. In Liberation Ecologies: environment, development, social movements, Peet, R, Watts, M (Ed.), pp. 86109. New York: Routledge.

Blaikie P. 1985. The Political Economy of Soil Erosion in Developing Countries. New York: Longman

Blaikie P., Brookfield H. 1987. Land Degradation and Society. London: Methuen

Bondi L. 1993. Locating Identity Politics. In Place and the Politics of Identity, Keith, M, Pile, S (Ed.), pp. 84-101. New York: Routledge.

Botkin D.B. 1990. Discordant Harmonies: A New Ecology for the Twenty-First Century. New York: Oxford University Press.

Braun B., Castree N., (Ed.).1998. Remaking Reality: Nature at the millenium. London: Routledge

Bryant R.L. 1998. Power, Knowledge and Political Ecology in the Third World: A Review. Progress in Physical Geography 22(1), 79-94.

Carney J. 1996. Converting the Wetlands, Engendering the Environment. In Liberation Ecologies: environment, development, social movements, Peet, R, Watts, M (Ed.), pp. 165-86. New York: Routledge. 
Castree N. 2001. Socializing Nature: Theory, Practice, and Politics. In Social Nature: Theory, Practice and Politics, Castree, N, Braun, B. Oxford: Blackwell.

Castree N., MacMillan T. 2001. Dissolving Dualisms: Actor-networks and the Reimagining of Nature. In Social Nature: Theory, Practice and Politics, Castree, N, Braun, B. Oxford: Blackwell.

Cronon W. 1983. Changes in the Land: Indians, Colonists, and the Ecology of New England. New York: Hill and Wang

Dahms C.W., Geils B.W. 1997. An assessment of forest ecosystem health in the Southwest. Rep. RM-GTR-295, U.S. Department of Agriculture, Forest Service, Rocky Mountain Forest and Range Experiment Station, Fort Collins, Colorado.

Daniggelis E. 1994. The Jangal's "Hidden" Wealth: Women's Behavioral Response to Food Scarcity in Eastern Nepal. Multipurpose Tree Species Network Report No. 22

de Janvry A. 1981. The Agrarian Question and Reformism in Latin America. Baltimore: John's Hopkins' University Press

Deere C.D. 1990. Household and Class Relations: Peasants and Landlords in Northern Peru. Berkeley: The University of California Press

Dodson S.I., (Ed.).1999. Readings in Ecology. New York: Oxford University Press. $461 \mathrm{pp}$.

Edwards D.M. 1996. Non-Timber Forest Products and Community Forestry: Are They Compatible? Banko Janakari 6(1), 3-8.

Escobar A. 1995. Encountering Development: The Making and Unmaking of the Third World

Freidberg S. 2001. To Garden, to Market: gendered meanings of work on an African urban periphery. Gender, Place and Culture 8(1), 5-24.

Gidwani V. 2000. Labored Landscapes: Agroecological Change in Central Gujarat, India. In Agrarian Environments: Rule, Resources and Representations in India, Agrawal, A, Sivaramakrishnan, K. Durham: Duke University Press.

Gilmour D.A. 1990. Resource Availability and Indigenous Forest Management Systems in Nepal. Society and Natural Resources 3, 145-58.

Gilmour D.A., Fisher R.J. 1991. Villagers, Forests and Foresters: The Philosophy, Processes and Practice of Community Forestry in Nepal. Kathmandu: Sahayogi Press. 212 pp.

Gleason H.A. 1939. The Individualistic Concept of the Plant Association. American Midland Naturalist 21

Graner E. 1997. The Political Ecology of Community Forestry in Nepal. Saarbrücken: Verl. für Entwicklungspolitik. 340 pp.

Grimm E.C. 1984. Fire and Other Factors Controlling the Big Woods Vegetation of Minnesota in the Mid-Nineteenth Century. Ecological Monographs 54(30), 291-311.

Guthman J. 1997. Representing Crisis: The Theory of Himalayan Environmental Degradation and the Project of Development in Post-Rana Nepal. Development and Change 28, 45-69.

Haraway D. 1991. Simians, Cyborgs and Women. New York: Routledge

Harris L. 2002. Irrigation, Gender and Social Geographies of the Changing Waterscapes of Southeastern Anatolia. under review

Harvey D. 1996. Justice, Nature and the Geography of Difference. Cambridge, MA: Blackwell 
Häusler S. 1993. Community Forestry: A Critical Assessment. The Case of Nepal. The Ecologist 23(3), 84-90.

Hecht S. 1985. Environment, Development and Politics: Capital Accumulation and the Livestock Sector in Eastern Amazonia. World Development 13(6), 663-84.

Horn S.P. 1998. Fire Management and Natural Landscapes in the Chirripó Páramo, Chirripó National Park, Costa Rica. In Nature's Geography: New Lessons for Conservation in Developing Countries, Zimmerer, KS, Young, KR (Ed.), pp. 125-46. Madison: The University of Wisconsin Press.

Ives J.D., Messerli B. 1989. The Himalayan Dilemma. Reconciling Development and Conservation. London and New York: The United Nations University and Routledge

Jarosz L. 1996. Defining Deforestation in Madagascar. In Liberation Ecologies: environment, development, social movements, Peet, R, Watts, M (Ed.), pp. 188-204. New York: Routledge Press.

Jodha N.S. 1986. Common Property Resources and Rural Poor in Dry Regions of India. Economic and Political Weekly 21(27), 1169-81.

Kanel K. 1993. Community Forestry and the 1993 Forest Legislation: Implications for Policy and Implementation. Banko Janakari 4(1), 2-5.

Kanel K., Varughese G. 2000. Economic Benefits of Decentralizing Forest Management: A Comparative Study of Four Community Forestry User Groups in Nepal. Presented at Constituting the Commons: Crafting Sustainable Commons in the New Millennium: Eighth Conference of the International Association for the Study of Common Property, Bloomington, Indiana, USA.

Kates R.W., II B.L.T., Clark W.C. 1990. The Great Transformation. In The Earth as Transformed by Human Action: Global and Regional Changes in the Biosphere over the Past 300 Years, II, BLT, Clark, WC, et al (Ed.), pp. 1-17. Cambridge: Cambridge University Press.

Khadka R.D. 1998. personal communication.

Kharel S. 1993. Women's Participation in Community Forestry: The Nepal-Australia Community Forestry Project's Experience. Banko Janakari 4(1), 73-5.

Kobayashi A. 1994. Coloring the Field: Gender, "Race," and the Politics of Fieldwork. Professional Geographer 46(1), 73-80.

Lakshman Y. 1993. What are Improved Seeds? An Epistemology of the Green Revolution. Economic Geography 69(3), 254-73.

Latour B. 1987. Science in Action. Cambridge: Harvard University Press

Latour B. 1993. We Have Never Been Modern. Cambridge: Harvard University Press

Lefebvre H. 1991. The Production of Space. Oxford: Blackwell

Longino H.E. 1990. Science as Social Knowledge: Values and Objectivity in Scientific Inquiry. Princeton: Princeton University Press. 262 pp.

Mahat T.B.S., Griffin D.M., Shepherd K.R. 1986. Human Impact on Some Forests of the Middle Hills of Nepal. Part 2. Some Major Impacts Before 1950 on the Forests of Sindhu Palchok and Kabhre Palanchok. Mountain Research and Development 6(4), 325-34.

Massey D. 1994a. Chapter Eight: Space, Place and Gender. In Space, Place, and Gender, Massey, D (Ed.), pp. 185-90. Minneapolis: The University of Minnesota Press.

Massey D. 1994b. Space, Place and Gender. Minneapolis: University of Minnesota Press 
McKean M.A. 1992. Success on the Commons: A Comparative Examination of Institutions for Common Property Resource Management. Journal of Theoretical Politics 43(3), 247-81.

Messerschmidt D.A. 1987. Conservation and Society in Nepal: Traditional Forest Management and Innovative Development. In Lands at Risk in the Third World: Local-Level Perspectives, Little, PD, Horowitz, MM, Nyerges, AE (Ed.), pp. 373-97. Boulder: Westview Press.

Metz J. 1991. A Reassessment of the Causes and Severity of Nepal's Environmental Crisis. World Development 19(7), 805-20.

Moore D.S. 1996. Marxism, Culture, and Political Ecology: Environmental struggles in Zimbabwe's Eastern Highlands. In Liberation Ecologies: environment, development, social movements, Peet, R, Watts, M (Ed.), pp. 188-204. New York: Routledge Press.

Nesbitt J.T., Weiner D. 2001. Conflicting Environmental Imaginaries and the Politics of Nature in Central Appalachia. Geoforum 32, 333-49.

Nightingale A.J. 2001. A 'Trialectic' of Community Forestry Management in Mugu District, Western Nepal: Power, Cultural Meanings and Ecology. Doctoral Dissertation thesis. University of Minnesota, Minneapolis. $362 \mathrm{pp}$.

Nightingale A.J. 2002a. The Nature of Gender: work, gender and environment. under review

Nightingale A.J. 2002b. Participating or Just Sitting In? The Dynamics of Gender and Caste in Community Forestry. Journal of Forestry and Livelihoods 2(1)

O'Neill R.V. 2001. Is it Time to Bury the Ecosystem Concept? (With Full Military Honors, of Course!). Ecology 82(12), 3275-84.

Ostrom E. 1992. The Rudiments of a Theory of the Origins, Survival, and Performance of Common-Property Institutions. In Making the Commons Work: Theory, Practice, and Policy, Bromley, D. San Francisco: ICS Press.

Peet R., Watts M. 1996a. Liberation Ecologies: environment, development, social movements. New York: Routledge Press

Peet R., Watts M. 1996b. Liberation Ecology: Development, sustainability, and environment in an age of market triumphalism. In Liberation Ecologies: environment, development, social movements, Peet, R, Watts, M. New York: Routledge Press.

Peluso N.L. 1995. Whose Woods are These? Counter-Mapping Forest Territories in Kalimantan, Indonesia. Antipode 27(4), 383-406.

Pigg S.L. 1996. The Credible and the Credulous: The Question of "Villagers' Beliefs" in Nepal. Cultural Anthropology 11(2), 160-201.

Radcliffe S.A. 1991. The Role of Gender in Peasant Migration: Conceptual Issues from the Peruvian Andes. Review of Radical Political Economics 23(2\&3), $129-47$.

Radcliffe S.A. 1992. Spontaneous Population Decentralization in Peru. In Decentralization in Latin America, Morris, A, Lowder, S. New York: Praeger.

Rangan H. 1997. Property vs. Control: The State and Forest Management in the Indian Himalaya. Development and Change 28(71-94)

Regmi M.C. 1988. An Economic History of Nepal 1846-1901. Varanasi: Nath Printing House

Richards J.F. 1990. Changes in Population and Society: Editorial Introduction. In The Earth as Transformed by Human Action: Global and Regional Changes in the Biosphere over the Past 300 Years, Turner, BL, Clark, WC, et al (Ed.), pp. 213. Cambridge: Cambridge University Press. 
Rocheleau D., Thomas-Slayter B., Wangari E. 1996. Gender and Environment: A Feminist Political Ecology Perspective. In Feminist Political Ecology: Global Issues and Local Experiences, Rocheleau, D, Thomas-Slayter, B, Wangari, E (Ed.), pp. 3-26. New York: Routledge.

Schroeder R.A. 1997. "Re-claiming" Land in The Gambia: Gendered Property Rights and Environmental Intervention. Annals of the Association of American Geographers 87(3), 487-508.

Schroeder R.A., Suryanata K. 1996. Gender, Class Power in Agroforestry Systems: Case Studies from Indonesia and West Africa Peet. In Liberation Ecologies: environment, development, social movements, Peet, R, Watts, M (Ed.), pp. 188-204. New York: Routledge.

Scoones I. 1997. The Dynamics of Soil Fertility Change: historical perspectives on environmental transformation from Zimbabwe. The Geographical Journal 163(2), 161-9.

Scott J. 1991. The Evidence of Experience. Critical Inquiry 17(3 (Summer)), 773-97.

Scott J.C. 1985. Weapons of the Weak: Everyday Forms of Peasant Resistance. New Haven: Yale University Press

Scott J.C. 1998. Seeing Like a State: How Certain Schemes to Improve the Human Condition Have Failed. New Haven: Yale University Press. 445 pp.

Shields R. 1999. Lefebvre, Love and Struggle: Spatial Dialectics. London and New York: Routledge. 225 pp.

Shrestha K. 2001. The backlash - Recent policy changes undermine user control of community forests in Nepal. In Forests, Trees, and People Newsletter: FAO.

Shrestha K.B. 1996. Community Forestry in Nepal; An Overview of Conflicts. Nepal Madhyasthata Samuha ICIMOD Discussion Paper(MNR Series No. 96/2), 112.

Shrestha N.K. 1999. personal communication.

Shrestha N.R. 1997. In the Name of Development: A Reflection on Nepal. Lanham, MD: University Press of America

Sneddon C.S. 2000. 'Sustainability' in ecological economics, ecology and livelihoods: a review. Progress in Human Geography 24(4), 521-49.

Soja E.W. 1996. The Trialectics of Spatiality. In Thirdspace: Journeys to Los Angeles and Other Real-and-Imagined Places (Ed.), pp. 53-82. Cambridge: Blackwell Publishers.

Springate-Baginski O., Soussan J., Dev O.P., Yadav N.P., Kiff E. 1998. Community Forestry in Nepal: Sustainability and Impacts on Common and Private Property Resource Management; Report on First Phase of Field Research, Environment Centre, Leeds University, Leeds, UK.

Stainton J.D.A. 1972. Forests of Nepal. New York: Hafner Publishing

Tilman D. 1999. The Ecological Consequences of Changes in Biodiversity: A Search for General Principles. Ecology 80(5), 1455-74.

Turner B.L., Clark W.C., Kates R.W., Richards J.F., Mathews J.T., Meyer W.B. 1990. The Earth as Transformed by Human Action: Global and Regional Changes in the Biosphere over the Past 300 Years. Cambridge: Cambridge University Press

Turner B.L.I. 1990. Understanding Transformations: Editorial Introduction. In The Earth as Transformed by Human Action: Global and Regional Changes in the Biosphere over the Past 300 Years, Turner, BLI, Clark, WC, et al (Ed.), pp. 655-7. Cambridge: Cambridge University Press. 
West P.C., Brechin S.R., (Ed.).1991. Resident Peoples and National Parks: Social

Dilemmas and Strategies in International Conservation. Tucson: The

University of Arizona Press

Zimmerer K. 1994. Human Geography and the "New Ecology": The Prospect and Promise of Integration. Annals of the Association of American Geographers 84(1), 108-25.

Zimmerer K., Young K. 1998. Nature's Geography: New Lessons for Conservation in Developing Countries. Madison: The University of Wisconsin Press

Zimmerer K.S. 1996. Discourses on Soil Loss in Bolivia: Sustainability and the search for socioenvironmental 'middle ground'. In Liberation Ecologies: environment, development, social movements, Peet, R, Watts, M (Ed.), pp. 110-24. New York: Routledge Press.

Zimmerer K.S. 2000. The Reworking of Conservation Geographies: Nonequilibrium Landscapes and Nature-Society Hybrids. Annals of the Association of American Geographers 90(2), 356-69.

\footnotetext{
${ }^{1}$ The research on community forestry involved an intensive case study in Western Nepal done during September 1993-July 1994, December-January 1997 and December 1998-October 1999. I conducted qualitative interviews on beliefs about land and ecology, oral histories, social relations and land use practices with one user-group, the district forest office and with national level development agencies. In addition, I observed community forestry meetings, forest harvesting and other daily negotiations over resource use. Finally, I analyzed aerial photos and conducted a vegetation inventory of the forest to gather other information on forest ecological conditions.

${ }^{2}$ These beliefs about Nepal are still widely held today.

${ }^{3}$ Current community forestry rules allow for the sale of forest products by user-groups. Not all groups chose to sell products, however. The sale of products from National Forests (as opposed to community forests) is subject to Forest Office approval.

${ }^{4}$ Within this work, however, ecological conditions are rarely taken to be also constitutive of the dialectic between social and cultural processes.

${ }^{5}$ The conditions under which community forestry operates in the hills is rapidly changing due to both the Maoist activities and efforts by the Forest Ministry to curtail the autonomy of user-groups. The Maoists have disrupted the functioning of user-groups in many areas although the extent to which they are preventing groups from effectively controlling forests is very unclear. The Forest Ministry is attempting to change laws related to CF to regain more control over forests. Nationally this has been a highly contested process and a national community forestry NGO has been lobbying on behalf of usergroups (Shrestha 2001).

'I use 'processes' here to highlight the dynamic nature of ecological change. The term is conventionally used only in relation to geo-chemical weathering of soils, water movements through ecosystems and other processes rather than to changes in structure and species composition as I use it here.

${ }^{7}$ Soja (1996) introduces the term 'trialectic' in his discussion of the production of space. He draws heavily from Lefebvre to outline three kinds of space all of which intersect to produce and reproduce space and spatial relations. I somewhat hesitantly invoke the term here as I am using it simply to flag the dialectical yet non-binary nature of my framework. Both Lefebvre and Soja conceive of three-way dialectical relationships to explore the importance of conceived, lived and perceived space (Lefebvre 1991, Shields 1999, Soja 1996). This kind of conceptualization embeds the symbolic within the material, the technocratic within the discursive and taken-for-granted daily lived experience of space, but also seeks to disrupt the dialectic by conceiving of affirmation-negation-other. This radical other is crucial for refusing the tendency to over-simplify the dialectic into temporal secession as it makes each of the terms subsumed and in tension with each other (Shields 1999). My analysis here similarly seeks to avoid cause and effect temporal relationships between the social-cultural and ecological. This kind of analysis allows me to explore the contradictions within land management regimes of decisions, discourses and practices rooted in power relations versus those rooted in seemingly inconsistent cultural relations and those that are influenced by ecological conditions. In other words, while obviously social and power relations are embedded within cultural practices, retaining an analytical distinction between them allows an analysis of how people draw on discourses and practices that seem
} 
antithetical to their social interests. This is most clearly reflected in Nepal in the tolerance of highercastes for the breaking of community forestry (CF) rules by the lower-castes. While the higher-castes have sufficient social and political power to enforce CF rules, they justify some blatant examples of rule-breaking by the lower-castes by saying "they are poor, what can they do?" (participant observation, February, 1994). When social relations and cultural practices are analytically collapsed into each other, it is more difficult to explore the importance of such apparent contradictions. Finally, by insisting on 'trialectical' relationships between the social, cultural and ecological, the ways in which they produce each other as opposed to impacting each other remains in the center of the analysis.

${ }^{8}$ Many of the Forest Department and NGO foresters I spoke with in Kathmandu had studied abroad where they learned scientific forest management, much of which was developed for the timber industry and not for multi-use forestry (Scott 1998).

${ }^{9}$ Under the kings and later the Rana Oligarchy that ruled from 1846-1951, government representatives and tax collectors in rural areas were hereditary, passed to the eldest son. The practice is no longer legal, but in Mugu, many politically powerful leaders claim leadership based on these kinds of kinshipbased claims.

${ }^{10}$ In other parts of Nepal, anecdotal evidence suggests these kinds of kinship-based claims are not necessarily as prevalent (although still important), in part because of differences in ethnicity and caste, and in part because community forestry has intersected with preexisting social relations and cultural practices in different ways (Khadka 1998, Shrestha 1999).

${ }^{11}$ The reasons for this rapid influx of migrants are complex and a detailed discussion is outside the scope of this paper. In brief, the establishment of government offices nearby brought office workers as well as other migrants who set up tea shops and other businesses.

${ }^{12}$ Transliterated Nepali words are given in italics in parentheses. All translations used in this paper are my own.

${ }^{13}$ Blue pine is a good timber tree and produces decent firewood.

${ }^{14}$ The extent to which forest degradation is an ecological problem in Nepal is contested and variable from one place to another. Most of this debate centers around the rate and extent of change (Gilmour and Fisher 1991, Ives and Messerli 1989, Metz 1991). The point here is that changes in forest coverregardless of the rate and extent of those changes-led to the formation of community forestry.

${ }^{15}$ When I asked people during my fieldwork if they collect wild foods from the forest, they inevitably told me that they don't, but the poorest people do. It was remarkable, however, the number of plants, particularly herbs, the same people could name in the local language, identify, and describe their virtues and handicaps in great detail. I therefore suspect that more people use these plants than they like to admit, which is consistent with the above argument because most people in Mugu are very poor and suffer from chronic food shortages. But it also shows the way in which use of particular resources is embedded within discourses of poverty.

${ }^{16}$ For example, community forestry is now promoted all over Asia and is developing in many places in the USA and Europe. 